\title{
Diel and depth profiles of DNA photodamage in bacterioplankton exposed to ambient solar ultraviolet radiation
}

\author{
Wade H. Jeffrey ${ }^{1, *}$, Ralph J. Pledger ${ }^{2}$, Peter Aas ${ }^{1}$, Silvia Hager ${ }^{3}$, Richard B. Coffin ${ }^{4}$, \\ Robin Von Haven ${ }^{1}$, David L. Mitchell ${ }^{2}$ \\ ${ }^{1}$ Center for Environmental Diagnostics and Bioremediation, University of West Florida, 11000 University Parkway, \\ Pensacola, Florida 32561, USA \\ ${ }^{2}$ MD Anderson Cancer Research Center, Science Park Research Division, Smithville, Texas 78957, USA \\ ${ }^{3}$ Department of Marine Biology, Institute of Zoology, University of Vienna, Althanstr. 14, A-1090 Vienna, Austria \\ ${ }^{4}$ United States Environmental Protection Agency, Environmental Research Laboratory, Gulf Breeze, Florida 32561, USA
}

\begin{abstract}
Bacteria play a central role in the cycling of nutrients and energy flow to higher trophic levels, yet the effects of ultraviolet-B (UV-B) radiation upon bacterioplankton have been largely overlooked. Using a highly specific radioimmunoassay, measurements of solar-induced DNA photodamage (cyclobutane pyrimine dimers) were taken in planktonic samples collected from the northern Gulf of Yexico. Diel patterns of dimer accumulation and repair were observed in both the bacterioplankton s17o: fraction $(<0.8 \mu \mathrm{m})$ and in the larger eukaryotic plankton size traction $(>0.8 \mu \mathrm{m}<120 \mu \mathrm{m})$, although damage induction was approximately twice as much in the bacterioplankton fraction. Depth profiles of $\mathrm{DN}$ l camage in the bacterioplankton size fraction during calm and moderate seas demonstrated the influence: of mixing on the distribution of UV radiation effects. During calm seas, damage was greatest in surface waters, decreased with depth, and could be defected to $10 \mathrm{~m}$. In moderate seas, however, no net accumulation of damage was observed, even at the surface. The results demonstrate that bacteria are more susceptible to UV-B damage and may scrve as a more sensitive indicator of UV stress than other microorganisms. Wave action and mixing strongly influence the effects of UV-B in surface waters, demonstrating that UV-B effects may not always be predictable from measures of UV radiation attenuation
\end{abstract}

KEY WORDS. Ultravıolet radıatıon DNA damage - Marine bacterioplankton

\section{INTRODUCTION}

There is now strong evidence that the flux of ultraviolet-B (UV-B) radiation ( 290 to $320 \mathrm{~nm}$ ) is increasing over major parts of the earth's surface (Farman et al. 1985, Stolarski et al. 1992). These observations and the potential for further increases in the future as a result of stratospheric ozone depletion have stimulated interest in the impact of UV-B on biological systems. The effect of ultraviolet radiation (UV-R) penetration in the marine environment has been demonstrated using biologic ultraviolet dosimeters designed to indicate the amount of biologically relevant UV-R reaching either

•E-mail: wjeffrey@uwf.edu surface or specific oceanic depths. Karentz \& Lutze (1990) used the rate of killing of a DNA-repairdeficient Escherichia coli strain and found biologically significant UV fluxes penetrated as deep as $30 \mathrm{~m}$ in Antarctic waters during ozone depletion events. Puskeppeleit et al. (1992) used Bacillus sphericus spores to monitor biologically active UV-R reaching the surface in Antarctica. Regan et al. (1992) developed dosimeters using either DNA or bacteriophage sealed in quartz tubes and reported UV-induced DNA damage to depths of $10 \mathrm{~m}$ in the Bahamas. UV-B has been shown to significantly reduce primary production to depths of $20 \mathrm{~m}$ during ozone hole events (Smith et al. 1992). UV-R has been implicated in coral bleaching (Jokiel \& York 1982, Dunlap et al. 1986, Logan et al. 1990) and 
inhibition of phytoplankton production (Collos et al. 1992, Helbling et al. 1992, Smith et al, 1992) and bacterial activity (Fujioka et al. 1981, Bailey et al. 1983, Sieracki \& Sieburth 1986, Herndl et al. 1993) Since phytoplankton serve as the base for most oceanic food webs, a large emphasis has been placed on the effect of UV-R on primary production (e.g. Bidigare 1989, Smith et al. 1992).

During the past $15 \mathrm{yr}$, the importance of bacteria in oceanic processes has become widely recognized. Bacteria have been found to account for up to $90 \%$ of the cellular DNA in oceanic environments (Paul \& Carlson 1984, Paul et al. 1985. Fuhrman et al. 1989, Coffin et al. 1990). The role of bacteria in elemental and nutrient cycling has received extensive study (e.g. Falkowski \& Woodham 1992). Bacteria have been found to play vital roles in carbon 'repackaging', providing a significant amount of organic material to higher organisms. This 'microbial loop' has been estimated to cycle up to $50 \%$ or more of primary production (Azam et al. 1983).

The effects of UV-R on bacterioplankton in aquatic ecosystems has received much less attention than has UV-R effects on primary producers. Only $5 \%$ of the papers listed $(n>300)$ in a recent bibliography of UV photobiology of aquatic bacteria, microalgae, and macroalgae (Karentz et al. 1994) were directed at studies of bacteria. Evidence suggests that UV-R may impose a chronic stress on marine bacteria. In the Chesapeake Bay, the uptake of amino acids, examined by microautoradiography, was increased when bacteria were shaded from UV-R (Bailey et al. 1983). Sieracki \& Sieburth (1986) reported that bacterial abundance was primarily affected by light in the UV-A wavelengths; both visible and UV-B light appeared to have no effect. When filters were used to shade bacterioplankton from UV-R, significantly higher biomass was consistently obtained in flask experiments. As little as $16 \%$ of the ambient UV-R was observed to have a significant effect on bacterial biomass (Sieracki \& Sieburth 1986). More recently, Herndl et al. (1993) reported that DNA and protein synthesis and degradative enzyme activities may be inhibited by as much as $40 \%$ from exposure to ambient UV-B. In addition, control of the activity of bacteria that are responsible for geochemical transformations in nitrogen and phosphorus cycles has been attributed to UV-R (Hooper \& Terry 1974, Horrigan et al. 1981, Horrigan \& Springer 1990).

Direct biological effects of UV-R result from absorption of specific wavelengths by specific macromolecules and the dissipation of the absorbed energy via photochemical reactions (Vincent \& Roy 1993) The major lethal and mutagenic effects of UV-R on marine organisms result from damage to DNA The type and extent of damage to DNA is a function of the wavelength and intensity of the exposure. UV-A generally causes indirect damage to DNA through the formation of chemical intermediates such as oxygen and hydroxyl radicals which interact with DNA to form strand breaks, alkali labile sites and DNA protein crosslinks (Peak \& Peak 1989). Conversely, adsorption. of energy from UV-B induces direct damage to DNA. The 2 major lesions induced by UV-B radiation are the cyclobutane pyrimidine dimer (CPD) and the pyrimidine-pyrimidone (6-4) photoproduct. The (6-4) photoproduct absorbs UV maximally at 310 to $315 \mathrm{~nm}$ and is photoisomerized to a Dewar pyrimidinone by these wavelengths (Mitchell \& Nairn 1989). UV-B causes direct inactivation of photosystem II but photosystem. I is much less sensitive (Iwanzik et al. 1983). Evidence also suggests that UV-B may alter protein and pigment composition in phytoplankton (reviewed by Vincent \& Roy 1993). Cellular defenses against UV-R vary among organisms. Many Antarctic marine organisms contain mycosporine-like amino acid compounds that absorb UV-R energy and may provide protection from UV-R exposure, resulting in a competitive advantage (Karentz et al. 1991b). Similar UV absorbing compounds may provide protecion for marine phytopiankton and cyanobacteria (Dunlap \& Chalker 1986, Karentz et al. 1991b, Marchant et al. 1991). Repair mechanisms also exist which remove photoproducts from DNA by a combination of photodependent and excision ('dark') repair pathways (Friedberg et al. 1995).

In this paper we report the first quantification of UV$B$ induced photolesions in DNA from natural communities of marine bacteria as a function of depth in the water column, and time of day, and in comparison to larger eukaryotic plankton.

\section{METHODS}

DNA photoproducts. Samples for DNA photoproducts (cyclobutane pyrimidine dimers, CPD) were collected by passing seawater through either $0.8 \mu \mathrm{m}$ or $0.22 \mu \mathrm{m}$ pore size polysulfone (Gelman Supor) filters. Filters were then collected and stored frozen in $2 \mathrm{oz}$ $(\sim 68 \mathrm{ml})$ polyethylene bags. DNA was extracted by removing the filter from the freezer and immediately crushing the filter before it thawed. Filter pieces were then poured into a $50 \mathrm{ml}$ Oak Ridge centrifuge tube and $5 \mathrm{ml}$ of STE (10 mM Tris, pH 8; 1 mM EDTA; 100 mM NaCl) containing $1 \%$ SDS (sodium dodecyl sulfate) was added to each. The tubes were capped, briefly vortexed and placed in a boiling water bath for 5 min. The lysate was aspirated and placed in a new centrifuge tube and the filter pieces washed with an additional $5 \mathrm{ml}$ of STE/SDS solution. The wash was combined with the lysate and extracted once with $10 \mathrm{ml}$ of chloroform:isoamyl alcohol (24:1) The aque- 
ous phase was collected after centrifuging at $4^{\circ} \mathrm{C}$ for $30 \mathrm{~min}$ at $3000 \mathrm{rpm}(1000 \times \mathrm{g})$. Nucleic acids were precipitated overnight at $-20^{\circ} \mathrm{C}$ after the addition of $10 \mu \mathrm{l}$ of a $25 \mathrm{mg} \mathrm{ml}^{-1}$ glycogen solution, 0.1 volume $3 \mathrm{M}$ sodium acetate $(\mathrm{pH} 5)$, and an equal volume of isopropanol. The precipitate was collected by centrifugation at $12000 \times g$ and $4^{\circ} \mathrm{C}$ for $30 \mathrm{~min}$. The pellet was washed with cold $70 \%$ ethanol and then resuspended in $1 \mathrm{ml}$ STE before transfer to a $2 \mathrm{ml}$ microfuge tube. The solution was re-precipitated as above and the final pellet resuspended in $200 \mu \mathrm{l} \mathrm{STE.} \mathrm{DNA} \mathrm{concentrations}$ were determined fluorometrically (Paul \& Myers 1982). Details for cyclobutane dimer radioimmunoassay may be found in Mitchell et al. (1985). This assay measures the binding of radiolabeled UV-irradiated DNA to antibody raised in rabbits against triplet-sensitized, UV-Birradiated DNA, conditions which induce thyminethymine cyclobutane dimers exclusively. Antiserum was raised in rabbits against DNA that received $100 \mathrm{~kJ}$ $\mathrm{m}^{-2}$ UV-C light. The specificity of these assays has been extensively scrutinized. Nick translated Clostridium perfringens DNA is used as a ligand. The radiolabeled ligand is irradiated with $10 \mathrm{~kJ} \mathrm{~m}^{-2} 254 \mathrm{~nm} \mathrm{UV}$ $\mathrm{C}$ light and $5 \mathrm{pg}$ added to a $1 \mathrm{ml}$ mixture of antiserum and sample DNA in TES $(10 \mathrm{mM}$ Tris, $1 \mathrm{mM}$ EDTA, $14 \mathrm{mM} \mathrm{NaCl}, \mathrm{pH}$ 7.5) buffer. The reactions are incubated at $37^{\circ} \mathrm{C}$ for 2 to $4 \mathrm{~h}$ followed by overnight incubation at $4^{\circ} \mathrm{C}$. DNA-bound antibodies are precipitated overnight at $4^{\circ} \mathrm{C}$ with goat anti-rabbit immunoglobulin and carrier immunoglobulin. After centrifugation, the pellet is dissolved in solubilizer and ${ }^{32} \mathrm{P}$ quantified by liquid scintillation counting. Under these conditions, antibody binding to an unlabeled competitor (sample DNA) results in reduced binding to the radiolabeled ligand (i.e. inhibition). Samples are compared to results obtained with standard DNA (e.g. pUC19) in which photoproduct formation is known.

Bacterial direct counts. Bacterial numbers were determined using DAPI and epifluorescence microscopy by the method of Porter \& Feig (1980).

Light measurements. Penetration of solar radiation in the water column was determined using a Biospherical Instruments (San Diego, CA) model PUV-500 profiling radiometer. Attenuation coefficients were determined from measurements made at noon each day.

Depth profiles. In September 1994, depth profiles of DNA photodamage in the water column were determined on 2 consecutive days in oligotrophic waters of the Gulf of Mexico $\left(29^{\circ} 52^{\prime} \mathrm{N}, 87^{\circ} 07^{\prime} \mathrm{W}\right.$ ). Conditions were very similar for both days, except that on September 7 the wind speed averaged approximately 15 knots and seas ran between 0.5 and $1 \mathrm{~m}$. In contrast the sea state on September 8 was completely calm. Water samples were collected at sunrise and again at 17:00 h each day. Samples from surface, $0.5 \mathrm{~m}, 1 \mathrm{~m}$, and $3 \mathrm{~m}$ were collected with a teflon-lined pneumatic pump (Wilden, Colton, CA). Samples from 5, 7.5, 10, 12.5, 15 , 20 , and $25 \mathrm{~m}$ were collected using Niskin bottles. Water samples were passed through a $0.8 \mu \mathrm{m}$ filter and the filtrate collected onto a $0.22 \mu \mathrm{m}$ pore size filter. The filter samples were frozen on dry ice and stored at $-70^{\circ} \mathrm{C}$ until DNA was extracted as described above.

Prior to sunrise (06:30 h) DNA dosimeters were deployed and held at a fixed depth suspended from buoys and were retrieved just after sunset (19:00 h). Buoys were designed carefully to avoid shading of any samples. Dosimeters were constructed using sterile $50 \mathrm{ml}$ quartz boiling flasks (Quartz Scientific, Fairport Harbor, $\mathrm{OH}$ ) containing a $0.1 \mathrm{mg} \mathrm{m}^{-1}$ calf thymus DNA solution in SSC $(0.15 \mathrm{M}$ sodium chloride, $0.015 \mathrm{M}$ sodium citrate, $\mathrm{pH}$ 7). Flasks were stoppered with sterile silicone stoppers and secured bulb side up to small ' $T$ ' frames fixed at depth to a weighted rope suspended from the buoys. Deployment and retrieval times prevented unintended exposure to UVR and gave dimer accumulation for the daily solar cycle. DNA solutions were removed from the quartz flasks and frozen until cyclobutane dimer accumulation was determined by radioimmunoassay.

${ }^{3} \mathrm{H}$-thmidine incorporation. Bacterial incorporation of ${ }^{3} \mathrm{H}$-thymidine into the trichloroacetic acid precipitable fraction was determined by the method of Chin-Leo \& Kirchman (1988). Surface water samples were collected via bucket sampling at each time point of the diel photodamage study. ${ }^{3} \mathrm{H}$-thymidine was added to a final concentration of $20 \mathrm{nM}$ and incubations were conducted for 30 min in the dark at a mbient seawater temperature.

Diel patterns and size fractions. A buoy was deployed from the RV 'Bellows' at $30^{\circ} 05^{\prime} \mathrm{N}, 86^{\circ} 50^{\prime} \mathrm{W}$ at 06:00 h on April 27, 1994 and surface waters (depth $<0.2 \mathrm{~m}$ ) were collected within $100 \mathrm{~m}$ of the buoy at $3 \mathrm{~h}$ intervals. Water was pumped aboard ship using a teflon lined pump (Wilden) and silicone tubing. All samples were pre-filtered through $120 \mu \mathrm{m}$ mesh Nitex screen. Water was filtered onto $0.8 \mu \mathrm{m}$ pore size polysulfone filters $(>0.8 \mu \mathrm{m}$ fraction or eukaryotic plankton) and this sample filter was immediately frozen in dry ice. The $<0.8 \mu \mathrm{m}$ filtrate was also collected onto a $0.22 \mu \mathrm{m}$ pore-size filter (bacterioplankton fraction). Cyclobutane dimers were determined in each DNA extract via radioimmunoassay (Mitchell et al. 1985).

\section{RESULTS}

\section{Depth profiles}

UV-R penetration in the water column was determined each day at 12:00 h (Fig. 1). Irradiance data suggests very similar light regimes for each of the 2 days of 

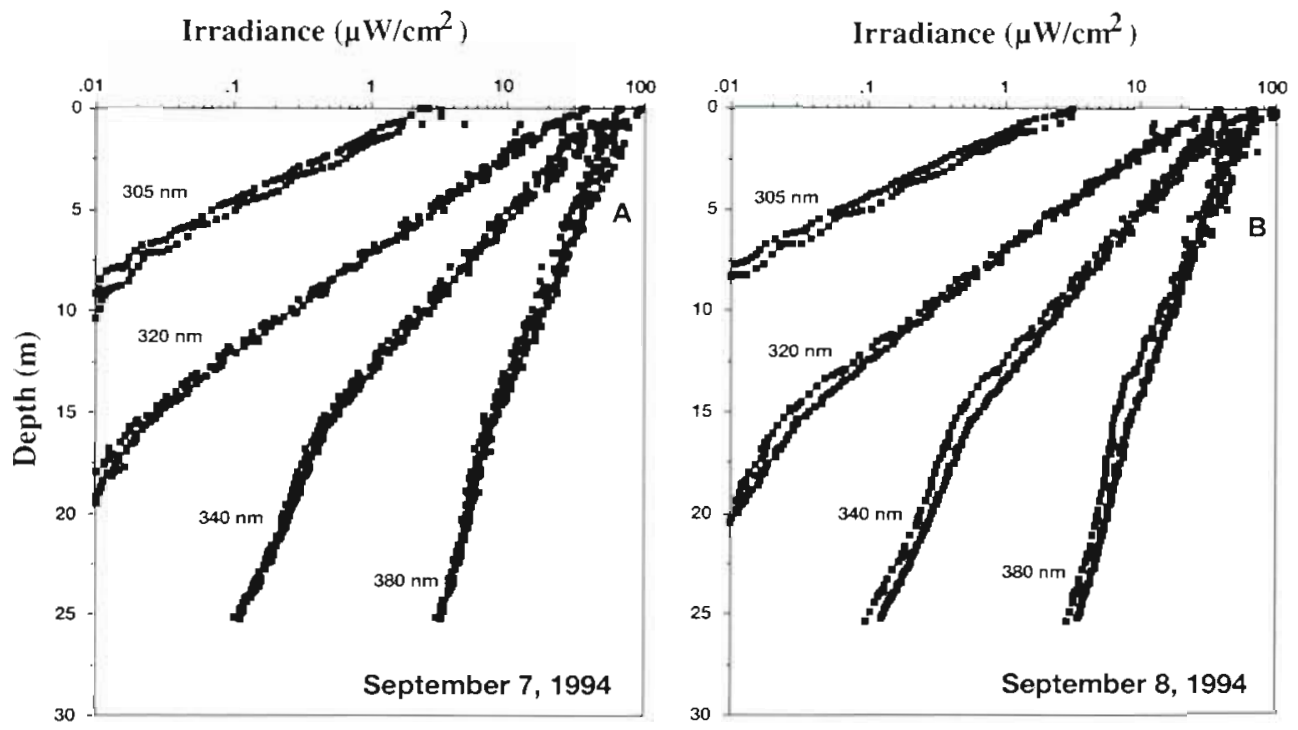

Fig. 1. UV radiation penetration in the water column as determined on (A) September 7 and (B) September 8, 1994, in oligotrophic waters of the Gulf of Mexico $\left(29^{\circ} 52^{\prime} \mathrm{N}, 87^{\circ} 07^{\prime} \mathrm{W}\right)$ using a Biospherical Instruments model PUV-500 profiling radiometer

the experiment. Attenuation coefficients $\left(k_{\mathrm{d}}\right)$ were determined at noon for each day for the 4 wavelengths measured by the PUV-500 radiometer. For 7 September, $k_{\mathrm{d}}$ values were $0.67 \mathrm{~m}^{-1}$ for $305 \mathrm{~nm}, 0.45 \mathrm{~m}^{-1}$ for $320 \mathrm{~nm}, 0.29 \mathrm{~m}^{-1}$ for $340 \mathrm{~nm}$ and $0.14 \mathrm{~m}^{-1}$ for $380 \mathrm{~nm}$. For 8 September, $k_{\mathrm{d}}$ values were $0.72 \mathrm{~m}^{-1}$ for $305 \mathrm{~nm}$, $0.44 \mathrm{~m}^{-1}$ for $320 \mathrm{~nm}, 0.29 \mathrm{~m}^{-1}$ for $340 \mathrm{~nm}$ and $0.14 \mathrm{~m}^{-1}$ for $380 \mathrm{~nm}$. There was no statistical difference between $k_{\mathrm{d}}$ values determined on September 7 and September 8, 1994 (Student's t-test).

CPD accumulation (Mitchell et al. 1985) was determined in solutions of calf thymus DNA held at fixed depths in quartz flasks (dosimeters) which were deployed prior to sunrise and retrieved after sunset (Fig. 2). Dosimeters may provide an indication of the maximum potential for damage to DNA (Regan et al.
1992). The profiles of CPD formation in the dosimeters vs depth were very similar on both September 7 and 8 . Radioimmunoassay showed 500 CPDs $\mathrm{Mbp}^{-1}$ (mega base pair) DNA on September 7 (Fig. 2A) and about $800 \mathrm{CPDs} \mathrm{Mbp}^{-1}$ DNA in surface samples on September 8 (Fig. 2B). These values are similar to those of Regan and co-workers who measured approximately $1000 \mathrm{CPDs} \mathrm{Mbp}^{-1}$ in purified DNA exposed to 1 solar day at the surface in tropical waters in July (Regan et al. 1992). The reduction in photoproduct formation with depth was exponential and correlated well with the attenuation of UV-B (305 nm) by seawater.

Photoproducts were also determined from indigenous bacterioplankton sampled from discreet depths at sunrise and again at sunset (Fig. 2). On September 8 , when there was no wind or wave action, CPD accum-

\section{Cyclobutane Dimers/Mb DNA}

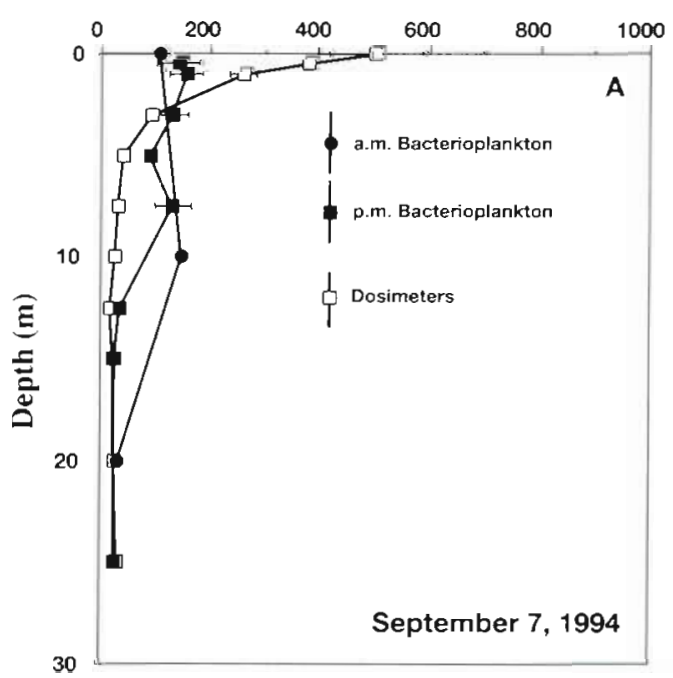

Cyclobutane Dimers/Mb DNA

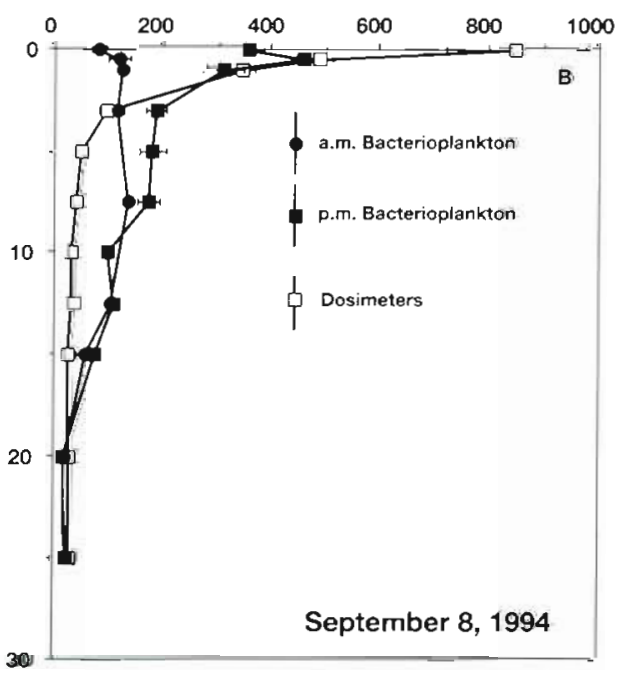

Fig. 2. DNA photodamage accumulation with depth in bacterioplankton and dosimeters in the northern Gulf of Mexico $\left(29^{\circ} 52^{\prime} \mathrm{N}\right.$ $87^{\circ} 07^{\prime} \mathrm{W}$ ) as measured at 06:30 h (a.m.) and 19:00 h (p.m.) on (A) September 7 and (B) September 8 
ulation in bacterioplankton declined with depth (Fig. 2B) as might be predicted from UV-R attenuation. DNA photodamage was greater at sunset than at sunrise to approximately $10 \mathrm{~m}$; below $10 \mathrm{~m}$ there was no discernable difference. CPD levels in the indigenous bacterial community showed a depth pattern similar to that of purified DNA but with some marked differences. Although exponential reduction in photoproduct formation was observed with depth, accumulation of CPDs in the indigenous bacterial DNA at the surface was substantially less than that found in purified samples contained in quartz containers. Integrated values of CPD accumulation in the top $3 \mathrm{~m}$ were about $50 \%$ less than those for purified DNA. Below $3 \mathrm{~m}$ there was significantly greater damage in the bacterioplankton compared with the dosimeters suggesting that residual photodamage ( -100 CPDs $\mathrm{Mbp}^{-1}$ or about 65 CPDs per bacterial cell) was present in the bacterial community prior to sunrise.

\section{Diel patterns and size fractions}

We anticipated that DNA damage levels would follow daily solar cycles with maximal damage occurring during peak exposure and minimal damage occurring just prior to sunrise. Details of this pattern were observed in samples collected from the northern Gulf of Mexico in April 1994 (Fig. 3). For several hours after sunrise (06:00 to 12:00 h), few detectable CPDs are induced in bacterioplankton DNA followed by a period of rapid CPD accumulation (12:00 to 15:00 h). After sunset, DNA damage is rapidly removed such that by

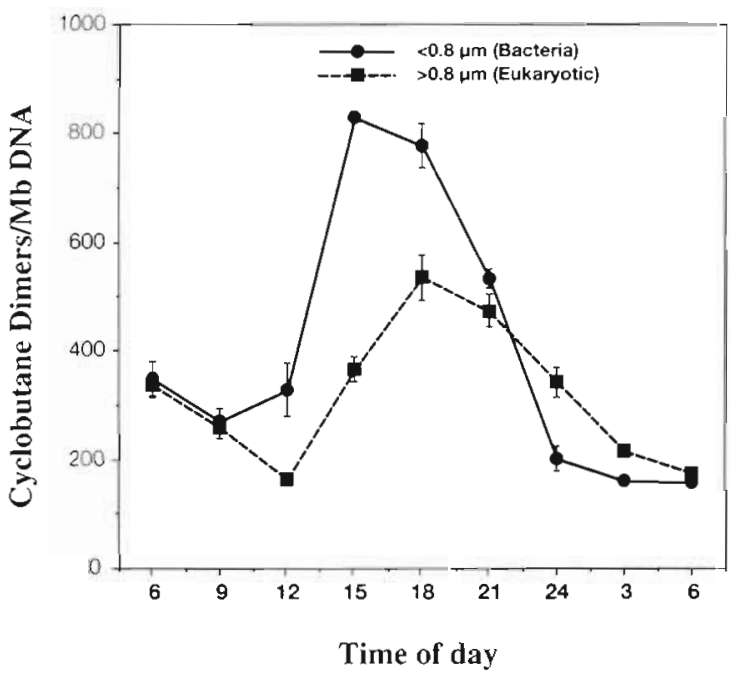

Fig. 3. Diel pattern of cyclobutane dimer accumulation in microbial size fractions in surface waters of the northern Gulf of Mexico

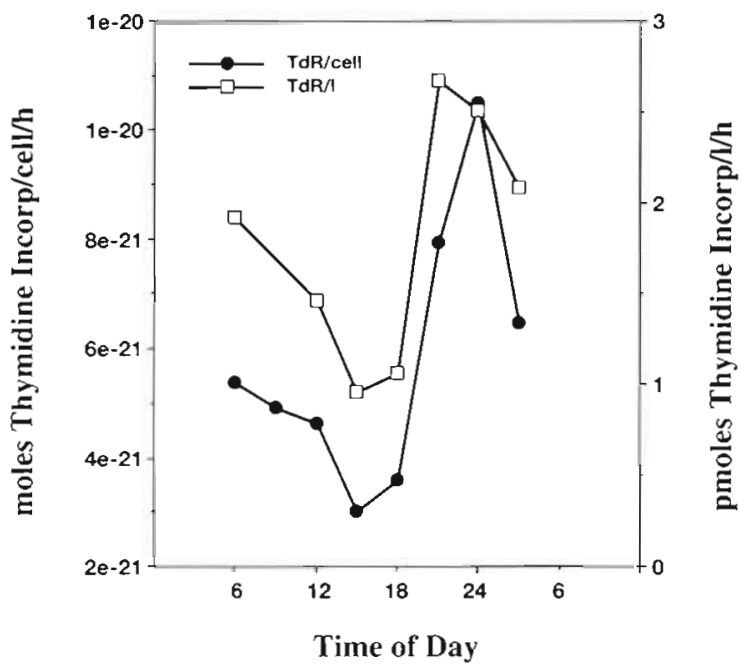

Fig. 4. Diel pattern of ${ }^{3} \mathrm{H}$-thymidine incorporation in surface waters in the northern Gulf of Mexico

sunrise the following morning, damage is back to a 'baseline' level. While similar patterns of damage induction and repair were observed in the larger cell size fraction, maximal photodamage in the bacterioplankton size fraction was almost double that in the $>0.8 \mu \mathrm{m}$ size fraction (presumably phytoplankton and other eukaryotes). On a previous research cruise (March 14 to 20,1994) surface waters were collected in the afternoon at 10 different locations along the Louisiana shelf. In 9 of 10 samples, the amount of photodamage was proportionally greater in the bacterial size fraction than in the $>0.8 \mu \mathrm{m}$ fraction (data not shown).

Diel patterns of ${ }^{3} \mathrm{H}$-thymidine incorporation were in stark contrast to the accumulation of cyclobutane dimers and showed a significant inhibition of bacterial activity during peak sunlight followed by rapid recovery after sunset (Fig. 4). Similar patterns were observed whether rates per volume or cellular rates were examined. Epifluorescence microscopy bacterial counts showed minimal change in bacterial density during the course of the experiment.

\section{DISCUSSION}

Bacterioplankton in the northern Gulf of Mexico have been found to suffer extensive DNA damage as a result of solar radiation. The extent of this damage varies according to time of day, depth in the water column, and cell size fraction. In addition, it would seem that the extent of damage would also be affected by other factors which influence the penetration of UV-R in the water column such as location and 
seasonality. The latent period between sunlight exposure (sunrise) and initial CPD formation may be analogous to the shoulder of a survival curve; at low UV-B doses all of the (sublethal) damage that is produced is repaired (Hall 1994). This is followed by a period of rapid $\mathrm{CPD}$ accumulation. The rate of accumulation during this phase $\left(110 \mathrm{CPDs} \mathrm{Mbp}^{-1} \mathrm{~h}^{-1}\right.$ ) is the sum of the rates of induction and removal by excision and photodependent repair processes, as well as dilution effects caused by cell death and cell division. From calculations on the normal distribution of photoproduct formation, peak levels of CPDs occur at about 16:00 h. During late afternoon (15:00 to $18: 00 \mathrm{~h})$, an equilibrium phase is observed when the rates of $C P D$ loss and gain are comparable. After the sun sets (18:00 h), the CPD levels fall rapidly ( 65 CPDs $\mathrm{Mbp}^{-1}$ $\left.\mathrm{h}^{-1}\right)$, removed by excision repair, cell mortality, and DNA dilution by cell growth and division. Bacterial direct counts and ${ }^{3} \mathrm{H}$-thymidine incorporation data suggests that immediately after sunset is a period of rapid recovery. Bacterial direct counts do not change appreciably during this period suggesting that the decline of CPDs is not due simpiy to 'dilution' of CPDs per unit DNA by synthesis of new DNA. Indeed, when using a common bacterial production conversion factor of $1 \times 10^{18}$ cells $\mathrm{mol}^{-1}$ thymidine incorporated (Riemann et al. 1987), maximal thymidine incorporation rates measured would only replace approximately $1 \%$ of the bacterial population per hour, while DNA damage was observed to decrease approximately 4 -fold in $6 \mathrm{~h}$. Repair as the primary mechanism of CPD removal is also supported by observations that the expression of the DNA repair gene recA also peaks just after sunset (W. Jeffrey, R. Miller \& R. Coffin unpubl.).

Although similar in shape, important differences were observed between the diel patterns of photodamage in bacterioplankton and in eukaryotic plankton (presumably phytoplankton). First, the overall level of damage accumulation (i.e. CPD $\mathrm{Mbp}^{-1} \mathrm{DNA}$ ) in the eukaryotic fraction was about half that of the bacterial fraction. This difference may be accounted for by the affect of cell size (surface area:volume) on photoproduct formation (Karentz et al. 1991a). Second, rates of both damage formation and loss in the eukaryotic fraction were half those observed in bacterioplankton and reached equilibrium later in the day. Specifically, damage accumulated at a rate of 58 CPDs $\mathrm{Mbp}^{-1} \mathrm{~h}^{-1}$, reaching a maximum level at $18: 30 \mathrm{~h}$. The slower rate of damage removal observed in the eukaryotic plankton fraction after sunset $\left(-29 \mathrm{CPDs} \mathrm{Mbp}^{-1} \mathrm{~h}^{-1}\right)$ reflects either a slower excision repair rate or a slower turnover rate. These ideas are consistent with current knowledge regarding differences between prokaryotes and eukaryotes in rates of cell division and excision repair (Friedberg 1985).
Observations of submaximal levels of photodamage in bacterial DNA at the surface and residual damage observed at sunrise may result from the interaction of similar biological processes. Concomitant with the production of CPDs in DNA by sunlight are their elimination by excision (dark) repair and photodependent repair mechanisms. In addition, DNA fragments (containing CPDs) resulting from cell death and Iysis would be removed by our filtration process. Hence, the net damage measured in the indigenous bacteria at sunset consists of the damage induced during the day less the damage removed by DNA repair and cell death and lysis. Related processes may also account for residual damage observed prior to sunlight exposure. Biphasic CPD repair is observed in several biological systems (Cantor \& Sutlow 1981) and may reflect a subclass of lesions that is refractory to excision repair. A similar phenomenon in bacteria would result in the observed residual damage. In addition, arrested growth and metabolism. (Fig. 4; Herndl et al. 1993, P. Aas \& W. Jeffrey unpubl.) resulting from UV-B exposure may also inhibit repair and could result in the accumulation of celis containing unrepaired photodamage. These ceils may persist in the bacterial community through the night and contribute to the residual damage levels observed at sunrise.

Mixing may also play an important role in determining the distribution of photodamage in the water column. In contrast to the dosimeters, little similarity was observed in the depth profiles for the indigenous bacterial communities on the 2 days. On September 7 , when the wind speed averaged approximately 15 knots and seas ranged between 0.5 and $1 \mathrm{~m}$, we observed no discernable pattern in CPD accumulation with depth (Fig. 2A). Indeed, damage accumulation at the surface after $12 \mathrm{~h}$ sunlight exposure was not significantly greater than that measured prior to sunrise. It is probable that mixing prevented damage from accumulating to the same extent as that observed on September 8 in the surface waters and that this mixing effect may have extended down to at least $10 \mathrm{~m}$. Indeed, under the conditions observed on September 7 , significant mixing has been calculated to have extended below $10 \mathrm{~m}$ (K. Bodge \& A. Raichle pers. comm.). Maximum wave orbital velocities through the water column were computed using linear wave theory. Wave conditions (height and period) were hindcast from the observed winds, fetch, and water depth. Estimated particle velocities ranged from approximately $0.7 \mathrm{~m} \mathrm{~s}^{-1}$ at the surface to approximately $0.2 \mathrm{~m} \mathrm{~s}^{-1}$ at $10 \mathrm{~m}$. Temperature profiles also indicated complete mixing in the upper $10 \mathrm{~m}$ on September 7. From these calculations we believe that little DNA damage would accumulate in bacteria at the surface before their conveyance to lower depths 
by wave action. Alternatively, mixing may serve to move damaged organisms to deeper depths where rates of photoreactivation may outweigh rates of UV$B$ induced damage, resulting in net decreases in DNA photoproducts.

It would be advantageous to use light exposure measurements to predict the amount of photodamage in bacterial and eukaryotic DNA. Irradiance measurements on September 7 and 8 showed that the percentages of $305,320,340$, and $380 \mathrm{~nm}$ light at $3 \mathrm{~m}$ were approximately $20,30,40$ and $>50 \%$ of that measured at the surface, respectively. As is consistent with the action spectrum for CPD induction (Rosenstein \& Mitchell 1987), the attenuation of CPDs in purified DNA in the water column correlated well with attenuation of $305 \mathrm{~nm}$ light. Even in conditions of limited physical disturbance (e.g. wave action and mixing on September 8), net photodamage accumulation in the indigenous plankton communities deviated substantially from the levels observed in purified DNA. On more typical days when seas are moderately agitated (e.g. September 7), DNA damage levels in the indigenous communities are distinct from the levels expected from the purified DNA dosimeter. We therefore conclude that DNA dosimeters are useful in ascertaining the attenuation of different wavelengths of light in the water column, but only in unique circumstances do they accurately reflect the photodamage in marine microplankton.

Measured depth profiles and the observed diel pattern of photoproduct induction in the DNA of bacterioplankton represent a coalition of divergent photochemical and photobiological processes. Added to the variability intrinsic in sampling natural communities and the complexity of the UV response at the molecular level is the interpretation of our data in the context of mixed plankton communities. Comparative studies on Antarctic phytoplankton have revealed great diversity in phytoplankton sensitivity to UV-B light and in the induction, photoreactivation, and excision repair of cyclobutane dimers and (6-4) photoproducts (Karentz et al. 1991a). Preliminary data on 2 species of bacterioplankton (i.e. Pseudomonas stutzeri and Vibrio natriegens) have shown similar diversity (W. Jeffrey \& $D$. Mitchell unpubl.). Therefore, in order to understand the effects of increased UV-B stress on species diversity in mixed bacterioplankton communities and, ultimately, trophic interactions that affect other components of nutrient flux, the photobiological response of bacterial families and even individual species should be examined.

Our results indicate that the bacterioplankton size fraction sustains higher levels of UV-B photoproducts in its DNA than the larger eukayotic size fraction. Given the importance of bacteria to energy flow and nutrient cycling in marine systems, the effect of UV-B on bacterial growth and productivity may have ecosystem implications. The importance of bacteria in marine ecosystems is exemplified by the observation that they not only suffer considerably more photodamage than do the eukaryotic plankton but often account for the bulk of cellular DNA in oligotrophic waters (Paul et al. 1985, Fuhrman et al. 1989, Coffin et al. 1990, Boehme et al. 1993). In other words, bacterioplankton often dominate microbial biomass and appear to be the primary target of UV-B radiation. Our data reflect the difficulties inherent in extrapolating UV-R effects on indigenous communities from direct photometric measurements of UV-R and fixed depth determinations in purified DNA samples, especially as might be encountered in high energy environments such as the Southern oceans. Low energy environments, e.g. certain lakes, may be less affected by mixing. In addition, coral reefs in which UV-R has been implicated in bleaching (Gleason \& Wellington 1993) are at fixed depths so that net effects would be determined less by wave driven mixing and more by water clarity and solar radiation intensity.

The survival of microorganisms exposed to significant daily doses of UV-R suggests that, under normal circumstances, an equilibrium exists between the rate of photodamage and repair and recovery. Stratospheric ozone attenuates the shorter, more damaging wavelengths of UV-B, and its reduction produces a shift in the ratios of UV-B:UV-A and UV-B:PAR (photosynthetically active radiation) (Smith et al. 1992). Ozone loss may thus shift the equilibrium between DNA damage formation and repair in marine organisms. Overcoming UV-B stress requires that energy be shifted from essential metabolic functions to DNA repair processes (Karentz et al. 1994), with trophic consequences to microbial food webs. Hence, should ozone deterioration continue, community structure may change and greater energy reserves may be required to overcome the increased photodamage. The cost of this energy loss to the ecosystem is difficult to assess but may have profound consequences on the marine environment.

Acknowledgements. This work was supported by U.S. Environmental Protection Agency Cooperative Agreement to W.H.J and D.L.M. through the Gulf Breeze Environmental Research Laboratory and by a grant from the CEC Environmental Program to Gerhard J. Herndl. We are grateful to Captain Robert Millender and the crew of the RV 'Bellows' for assistance with freld sampling. We thank Dean Pakulskl for comments on an earlier draft of this manuscript and John Morrow for assistance with light measurements. Thanks to J. E. Jeffrey for many useful discussions. 


\section{LITERATURE CITED}

Azam F, Fenchel I, Field J, Gray J, Meyer-Reil LA, Thingstad $F$ (1983) The ecological role of water column microbes in the sea. Mar Ecol Prog Ser 10:257-263

Bailey CA, Nelhof RA, Tabor PS (1983) Inhibitory effect of solar radiation on amino acid uptake in Chesapeake Bay bacteria. Appl Environ Microbiol 46:44-49

Bidigare RR (1989) Potential effects of UV-B radiation on marine organisms of the Southern Ocean: distributions of phytoplankton and krill during austral spring. Photochem Photobiol 50:469-477

Boehme J, Frischer ME, Jiang SC, Kellogg CA, Pichard S, Rose JB, Steinway C, Paul JH (1993) Viruses, bacterioplankton, and phytoplankton in the southeastern Gulf of Mexico: distribution and contribution to oceanic DNA pools. Mar Ecol Prog Ser 97:1-10

Cantor GJ, Sutlow RB (1981) Fate and extent of DNA repair in nondividing human diploid fibroblasts. Cancer Res 41: 819-825

Chin-Leo G, Kirchman DL (1988) Estimating bacterial production in marine waters from the simultaneous incorporation of thymidine and leucine. Appl Environ Microbiol 54:1934-1939

Coffin RB, Velinsky D, Devereux R, Price WA, Cifuentes L (1990) Stable carbon isotope analysis of nucleic acids to trace sources of dissolved substrates used by estuarine bacteria. Appl Environ Microbiol 56:2012-2020

Collos Y, Descolas-Gros C, Fontugne M, Mortain-Bertrand A, Chretiennot-Dinet $\mathrm{MJ}$ (1992) Carbon and nitrogen dynamics during growth degradation of phytoplankton under natural surface irradiance. Mar Biol 112:491-496

Dunlap WC, Chalker BE (1986) Identification and quantitation of near UV absorbing compounds ( $S-320$ ) in a hermatypic scleractinian. Coral Reefs 5:155-159

Dunlap WC, Chalker BE, Loiver JK (1986) Bathymetric adaptations of reef building corals at Davies Reef, Great Barrier Reef, Australia. III. UV-B absorbing compounds. J Exp Mar Biol Ecol 104:239-248

Falkowski PG, Woodham AD (1992) Primary production and biogeochemical cycles in the sea. Plenum Press, New York

Farman JC, Gardiner BG, Shanklin JD (1985) Large losses of total ozone in Antarctica reveal seasonal $\mathrm{CLO}_{x} / \mathrm{NO}_{x}$ interaction. Nature 315:207-210

Friedberg EC (1985) DNA repair WH Freeman \& Co, New York

Friedberg EC, Walker GC, Siede W (1995) DNA repair and mutagenesis. ASM Press, Washington, DC

Fuhrman JA, Sleeter TD, Carlson CA, Proctor LM (1989) Dominance of bacterial biomass in the Sargasso Sea and its ecological implications. Mar Ecol Prog Ser 57:207-217

Fujioka RS, Hashimoto $\mathrm{HH}$, Siwak EB, Young RHF (1981) Effect of sunlight on survival of indicator bacteria in seawater. Appl Environ Microbiol 41:690-696

Gleason DF, Wellington GM (1993) Ultraviolet radiation and coral bleaching. Nature 365:836-838

Hall EJ (1994) Radiobiology for the radiobiologist, 4th edn JB Lippincott Co, Philadelphia

Helbling EW, Villafane V, Ferrario M, Holm-Hansen O (1992) Impact of natural ultraviolet radiation on rates of photosynthesis and on specific marine phytoplankton species. Mar Ecol Prog Ser 80:89-100

Herndl GJ, Müller-Niklas G, Frick J (1993) Major role of ultraviolet- $B$ incontrolling bacterioplankton growth in the surface layer of the ocean. Nature 361:717-719

Hooper AB, Terry KR (1974) Photoinactivation of ammonia oxidation in Nitrosomonas. J Bacteriol 119:899-906
Horrigan SG, Carlucci AF, Williams PM (1981) Light inhibition of nitrification in sea-surface films. J Mar Res 39: $557-565$

Horrigan SG, Springer AL (1990) Oceanic and estuarine ammonium oxidation: effects of light. Limnol Oceanogr $35: 479-482$

Iwanzik W, Tevini M, Dohnt G, Voss M, Weiss W, Graber P, Renger G (1983) Action of UV-B radiation on photosynthetic primary reactions in spinach chloroplasts. Physiol Plant 58:401-407

Jokiel PL, York RH (1982) Solar ultraviolet photobiology of the reef coral Pocillopora damicornis and symbiotic zooxanthellae. Bull Mar Sci 32:301-315

Karentz D, Bothwell ML, Coffin RB, Hansen A, Herndl GJ Kilham SS, Lesser MP, Lindell M, Moeller RE, Morris DP, Neale PJ, Sanders RW, Weiler CS, Wetzel RG (1994) Impact of UVB radiation on pelagic freshwater ecosystems: report of working group on bacteria and phytoplankton. Arch Hydrob Beih Ergeb Limnol 43:31-69

Karentz D, Cleaver JE, Mitchell DL (1991) Cell survival characteristics and molecular responses of antarctic phytoplankton to ultraviolet-B radiation. J Phycol 27:326-341

Karentz D, Lutze LH (1990) Evaluation of biologically harmful ultraviolet radiation in Antarctica with a biological dosimeter designed for aquatic environments. Limnol Oceanogr 35:549-561

Karentz D, McEuen FS, Land MC, Dunlap WC (1991b) Survey of mycosporine-like amino acid compounds in Antarctic marine organisms: potential protection from ultraviolet exposure. Mar Biol 108:157-166

Logan A, Halcrow K, Tomascik T (1990) UV excitation-fluorescence in polyp tissue of certain scleractinian corals from Barbados and Bermuda. Bull Mar Sci 46:807-813

Marchant HJ, Davidson AT, Kelly GJ (1991) UVB protecting compounds in the marine alga Phaeocyctis pouchetii from Antarctica. Mar Biol 109:391-395

Mitchell DL, Haipek CA, Clarkson JM (1985) (6-4) Photoproducts are removed from the DNA of UV-irradiated mammalian cells more efficiently than cyclobutane pyrimidine dimers. Mutat Res 143:109-112

Mitchell DL, Nairn RS (1989) The biology of the (6-4) photoproduct. Photochem Photobiol 49:805-819

Paul JH, Carlson D (1984) Genetic material in the marine environment: implication for bacterial DNA. Limnol Oceanogr 29:1091-1097

Paul JH, Jeffrey WH, DeFlaun MF (1985) Particulate DNA in subtropical oceanic and estuarine planktonic environments. Mar Biol 90:95-101

Paul JH, Myers B (1982) Fluorometric determination of DNA in aquatic microorganisms by use of Hoechst 33258. Appl Environ Microbiol 43:1393-1399

Peak MJ, Peak V (1989) Solar-ultraviolet induced damage to DNA. Photodermatol 6:1-15

Porter KG, Feig YS (1980) The use of DAPI for identifying and counting aquatic microflora. Limnol Oceanogr 25 $943-948$

Puskeppeleit M, Quintern L, el Naggar S, Schott JU, Eschweiler U, Horneck G, Bucker H (1992) Long-term dosimetry of solar UV radiation in Antarctica with spores of Bacillus subtilis, Appl Environ Microbiol 58:2355-2359

Regan JD, Carrier WL. Gucinski H, Olla BL, Yoshida H, Fujimura RK, Wicklund RI (1992) DNA as a solar dosimeter in the ocean. Photochem Photobiol 56:35-42

Riemann B, Bjornsen PK, Newell S, Fallon R (1987) Calculation of cell production of coastal marine bacteria based on measured incorporation of $\left[{ }^{3} \mathrm{H} \mid\right.$ thymidine. Limnol Oceanogr 32:471-476 
Rosenstein BS, Mitchell DL (1987) Action spectra for the induction of pyrimidine (6-4) pyrimidone photoproducts and cyclobutane pyrimidine dimers in normal human skin fibroblasts. Photochem Photobiol 45:775-786

Sieracki ME, Sieburth JMcN (1986) Sunlight-induced growth delay of planktonic marine bacteria in filtered seawater. Mar Ecol Prog Ser 33:19-27

Smith RC, Prezelin BB, Baker KS, Bidigare RR, Boucher NP, Coley T, Karentz D, MacIntyre S, Matlick HA, Menzies D,

This article was presented by J. Fuhrman (Senior Editorial Advisor), Los Angeles, Callfornia, USA
Ondrusek M, Wan Z, Waters KJ (1992) Ozone depletion; ultraviolet radiation and phytoplankton biology in antarctic waters. Science 255:952-959

Stolarski R, Bojkov R, Bishop L, Zerefos C, Staehelin J, Zawodny J (1992) Measured trends in stratospheric ozone. Science 256:342-349

Vincent WF, Roy $S$ (1993) Solar ultraviolet-B radiation and aquatic primary production: damage, protection, and recovery. Environ Rev 1:1-12

Manuscript first received: September 29, 1995 Revised version accepted: January 22, 1996 